\title{
AKUNTABILITAS KINERJA AKUNTAN PENDIDIK BERDASARKAN KOMPETENSI AKUNTAN DAN ETIKA PROFESIONAL ( Studi Empiris Pada Perguruan Tinggi Swasta di Bogor )
}

\section{AKUNTABILITAS PERFORMANCE ACCOUNTANT EDUCATOR PURSUANT TO INTEREST ACCOUNTANT AND PROFESSIONAL ETHICS (Empirical Study At College Of Private sector in Bogor)}

\author{
M.N. Mukmin, H. Wulansari \\ Program Studi Akuntansi Fakultas Ekonomi Universitas Djuanda Bogor \\ Jl. Tol Ciawi No. 1, Kotak Pos 35, Kode Pos 16720, Telp/Fax : (0251) 8245155 \\ E-mail : mas.nur.mukmin@unida.ac.id, wulanhesti8@gmail.com
}

\begin{abstract}
This research has purpose to know influence of competence accountant educator, professional ethics accountant performance of educator accountant at private university in Bogor. Population that is accountant educator. Samples amounted to 75 respondents from 9 private universities Bogor. Sampling method this research using non probability sampling. The analytical method used this research validity test, reliability test, classical assumption test, multiple regression analysis, coefficient of determination $\left(R_{2}\right), F$ test and T test. Based the results the research, it is known that the competence of educators accountant simultaneously and partially influence the accountability of the accountant's performance of educators, professional ethics simultaneously influence but not partially influence the accountant's performance accountant accountability. Contribution amount influence of competence of educator accountant, professional ethics can use to explain accountant performance of 46.7 percent.
\end{abstract}

Keywords: Competence, professional ethics, performance accountability

\begin{abstract}
ABSTRAK
Penelitian ini bermaksud memahami dampak etika profesional, kompetensi akuntan pendidik atas akuntabilitas kinerja akuntan pendidik pada PTS di Bogor. Populasi observasi ini ialah akuntan pendidik. Sebanyak 75 responden dari 9 PTS di Bogor merupakan sampel dalam penelitian. Pengambilan sampel observasi memakai metode non probability sampling. Metode analisis menggunakan uji validitas, uji reliabilitas, uji asumsi klasik, analisis regresi berganda, koefisien determinasi $\left(\mathrm{R}_{2}\right)$, uji simultan dan parsial. Berdasarkan hasil penelitian, diketahui bahwa kompetensi akuntan pendidik mempengaruhi simultan serta parsial atas etika profesional, akuntabilitas kinerja akuntan pendidik mempengaruhi simultan tetapi tidak mempengaruhi parsial atas akuntabilitas kinerja akuntan pendidik. Besarnya kontribusi dampak etika profesional, kompetensi akuntan pendidik dapat menjelaskan akuntabilitas kinerja akuntan pendidik 46,7 persen.
\end{abstract}

Kata Kunci: Kompetensi, Etika Profesional, Akuntabilitas Kinerja 


\section{PENDAHULUAN}

Seiring perkembangan zaman, kebutuhan akan akuntan sangat meninggi pada semua bidang. Hingga awal tahun ada 100.000 organisasi membutuhkan tenaga akuntan untuk pengelola keuangan baik pemerintahan maupun swasta. Sementara Pusat Pembinaan dan Jasa Penilai (PPAJP) Kementerian Keuangan menginventarisasikan pekerja ada kurang dari 17.000, hal tersebut menggambarkan bahwa Indonesia masih memerlukan tenaga akuntan profesional, di lain sisi Indonesia segera menghadapi masa MEA. Pada era tersebut pekerja sejumlah negara ASEAN mempunyai harapan kerja pada daerah itu. Terlebih bagi pekerja yang dibekali oleh sertifikasi profesi internasional, hal ini diperuntukkan juga untuk profesi sebagai akuntan. Guna menyediakan peluang dan permintaan pasar, jasa keuangan profesional perlu memperbaiki kinerjanya. Persoalan etika selalu hadir pada dunia auditing misalnya pentingnya fungsi akuntan pendidik. Tugas akuntan pendidik mencanangkan nilai etika profesional sebagai akuntan pada mahasiswa ajar. Akuntan pendidik punya tugas guna pendidikan akuntansi, melaksanakan penelitian dan pembaharuan akuntansi mengajar, penataan program akuntansi. Etika profesional diperlukan untuk tahu hal baik serta hal yang buruk sehingga dalam hal mengambil keputusan tersebut dapat dipertanggungjawabkan dan bermoral. Fenomena akuntan pendidik mengajar tidak berdasarkan garis besar pengajaran telah ada di awal beberapa oknum tenaga pengajar. Budaya pengawasan yang tidak berlangsung lancar dan semestinya di mana dosen sering meninggalkan ruangan dan lebih memilih berdiri di luar ruangan bercengkrama dengan pengawas lainnya, beberapa oknum dosen melimpahkan tugasnya kepada petugas administrasi untuk mengawasi jalannya ujian. Profesi akuntan pendidik dinilai penting sebab diperlukan untuk peningkatan akuntan itu sendiri, karena berkat ajaran mereka para akuntan terdidik. Akuntan pendidik hendaklah melakukan proses pemberian pemahaman pelajaran (transfer knowledge) kepada mahasiswa, informasi teknologi, meningkatkan ilmu pengetahuan melalui pendidikan. Maka dari itu, penting sekali memahami dampak etika profesional, kompetensi akuntan pendidik atas akuntabilitas kinerja akuntan pendidik PTS Bogor ditujukan dengan meningkatkan kompetensi akuntablitas kinerja pendidik.

Menurut Wibowo (2012), kompetensi ialah kecakapan melaksanakan pekerjaan dari keahlian serta kepandaian yang dibantu sikap kegiatan tersebut. Kompetensi ialah deskripsi dilaksanakan dalam bekerja, serta wujud pekerjaan tersebut. Dalam melakukan suatu profesi, harus punya kemampuan berupa perilaku, keterampilan, ilmu sesuai bidang pekerjaan. Berdasar pada penjeasan tersebut, kompetensi guru diartikan dengan representasi yang dilakukan seorang guru dalam melakukan pekerjaannya, berbentuk aktivitas, sikap atau hasil dari pendidikan (Suyanto dan Jihad 2013). Menurut Jhonson (dalam Yuthadiana, 2015), kompetensi terbagi menjadi 3 bagian, seperti kompetensi pribadi, kompetensi profesional dan kompetensi sosial.

Langkah memperoleh pengembangan kompetensi untuk mengoptimalkan tingkat kompetensi (Spencer \& Spencer dalam Vina Yuthadiana, 2015) diantaranya :

1. Pengakuan, simulasi memberi kesempatan peserta mengenali kompetensi bisa mengasumsikan seorang berkinerja tinggi jadi seseorang dapat berjalan dari pengalaman simulasi tersebut.

2. Pemahaman, perintah termasuk modelling sikap mengenai kompetensi, bagaimana terapannya.

3. Pengkajian, umpan balik pada peserta menganai punya berapa banyak kompetensi peserta (menimbangnimbang skor peserta).

4. Umpan balik, pendidikan dimana peserta bisa mempraktekkan kompetensi serta dapat umpan balik peserta bisa melakukan tugas tertentu berbanding dengan seseorang yang berkinerja tinggi.

5. Permohonan kerja, memakai kompetensi pada hidup nyata.

Akuntan pendidik ialaj akuntan yang bertugas dalam pendidikan akuntansi, melakukan penelitian dan pengembangan akuntansi, mengajar, serta penyusunan kurikulum akuntansi Perguruan Tinggi. Akuntan pendidik diharuskan punya tingkat pendidikan tinggi, mampu mengefektifkan ilmu penelitian. Intinya akuntan diharuskan memelihara serta menumbuhkan keterampilan menyelenggarakan semua pekerjaan (Reski, 2013). 
Ada beberapa kegiatan akuntan pendidik seperti mengatur kurikulum pendidikan akuntansi, memberi pengajaran pada sejumlah diskusi pendidikan, dan melaksanakan ruset pengembangan ilmu aknuntansi.

Etika profesi bersumber pada panduan sikap berhubungan dengan profesi itu. Dasarnya semua hal berkaitan dengan sosial mempunyai panduan untuk mengatur suatu kegiatan berjalan di setiap pribadi yang melaksanakannya, seperti etika profesi.

Kinerja bisa dimaknakan prestasi kerja atau pelaksanaan kerja atau hasil unjuk kerja. Kinerja akuntan pendidik ialah kemampuan akuntan pendidik dalam melaksanakan pekerjaannya (Rachmawati dan Daryanto, 2013). Kinerja baik kalau hasil diraih melalui penetapan standar.

\section{PENGEMBANGAN HIPOTESIS}

\section{Pengaruh Kompetensi Akuntan Pendidik atas Akuntabilitas Kinerja Akuntan Pendidik}

Kompetensi ialah keahlian untuk melakukan profesi berlandaskan keahlian juga kemampuan didorong sikap kerja berdasar pekerjaan tersebut (Wibowo, 2012). Kinerja merupakan unjuk kerja (performace). Kinerja bisa juga diasumsikan prestasi kerja atau operasionalisasi kerja atau hasil unjuk kerja. Kinerja yakni kesuksesan orang menjalankan pekerjaan, tanggungjawab, keahlian menggapai harapan serta ukuran standar. Keahlian yang ditunjukkan akuntan pendidik melaksanakan pekerjaannya ialah definisi kinerja akuntan pendidikan. Kinerja dikatakan baik dan sesuai penetapan standar (Rachmawati dan Daryanto, 2013), sehingga adanya kompetensi diharapkan bisa mengoptimalkan kinerja akuntan pendidik.

$\mathrm{H}_{1}$ : Kompetensi akuntan berpengaruh dan signifikan atas akuntabilitas kinerja akuntan pendidik.

\section{Pengaruh Etika Profesional atas Akuntabilitas Kinerja Akuntan Pendidik}

Etika yakni suatu bagaimana dan dimana bagian utama makulat dipelajari mutu ataupun kualitas yang jadi pengkajian berdasar standar dan pandangan moral. Mulanya tiap-tiap perihal berkaitan ikatan sosial melalui individu lainnya, punya aturan dan norma yang menangani bagaimana kegiatan itu terbentuk di tiap-tiap pribadi yang dijalaninya, sama juga dengan etika profesi. Cara memperoleh profesi impian salah satunya ialah memaklumi etika profesi itu penting (Poerwadarminta dalam Bertens, 2013). Kinerja akuntan pendidik yaitu kesanggupan ditunjukkan dengan akuntan pendidik pada pelaksanaan pekerjaannya. Kinerja dikatakan baik dan membahagiakan jikalau capaian hasil sesuai dengan penetapan ukuran (Rachmawati dan Daryanto, 2013), sehingga harapan adanya etika profesional bisa menggapai kinerja akuntan pendidik.

\section{$\mathrm{H}_{2}$ : Etika profesional tidak berpengaruh signifikan atas akuntabilitas kinerja akuntan pendidik.}

\section{METODE PENELITIAN}

Metode dalam penelitian yakni verifikatif, yakni memverifikasi benarnya sebuah hipotesis. Sedangkan jenis data yaitu kuantitatif, yaitu hasil pengolahan secara statistic dan matematis dari jawaban kuesioner seluruh responde, dan data kualitatif yakni data berupa kalimat, skema, dan gambar. Objek penelitian PTS Bogor. Sementara itu penelitian didapat data primer berupa data yang langsung diperoleh dari narasumber yang dianggap berpeluang bisa memperoleh informasi sesuai dan sebenarbenarnya di lapangan, data sekunder berupa data pendukung data primer didapatkan pada bacaan serta tulisan yang didapatkan di organisasi tempat dilakukannya penelitian. Jumlah sampel yang diambil berjumlah 75 dosen/responden.

Variabel eksogen/ independen penelitian yakni Kompetensi Akuntansi Pendidik $\left(\mathrm{X}_{1}\right)$ yang diartikan sebagai seperangkat pengetahuan, keterampilan dan karakter yang dipunyai, dijiwai, dikuasai dan diwujudkan oleh akuntan pendidik saat melakukan pekerjaan profesionalnya, dimensinya meliputi kompetensi pedagodik, kompetensi profesional, kompetensi kepribadian dan kompetensi sosial; Etika Profesional $\left(\mathrm{X}_{2}\right)$ merupakan patokan moral untuk bertindak akuntan pendidik dalam melaksanakan tugas profesinya, dibatasi oleh seperangkat aturan dan standar berupa kode etik, meliputi dimensi kepentingan publik, integritas, objektivitas dan independen serta due care. Sedangkan variabel endogen/ dependen yakni Akuntabilitas Kinerja Akuntan Pendidik (Y) 
yang merupakan kemampuan mempertanggungjawabkan semua kegiatan yang dilaksanakan sebagai pendidik pada orang berkepentingan sesuai dengan ketentuan peraturan perundang-undangan, adapun indikator dari Akuntabilitas Kinerja Akuntan Pendidk, meliputi: Proses Belajar Mengajar, Kapabilitas (Kompetensi Dosen), Ketersediaan Sarana.

\section{Populasi, Sampel, Teknik Pengambilan Sampel}

Populasi penelitian yaitu dosen tetap PTS Bogor yang mengajar mata kuliah akuntansi. Adapun lokasi penelitian terdiri dari Universitas Djuanda Bogor, Universitas Nusa Bangsa, Universitas Pakuan, STIE Kalpataru, STIE Kesatuan, STIE Triguna, AMIK BSI Bogor, POLITEKNIK Kent, STIE Bina niaga

Sampel dihitung menggunakan rumus slovin (Riduwan, 2013):

dimana:

$$
\mathrm{n}=\frac{\mathrm{N}}{\mathrm{N} \cdot \mathrm{d}^{2}+1}
$$

$\mathrm{n}=$ Sampel

$\mathrm{N}=$ Populasi

$\mathrm{d}=$ Penetapan presisi, yaitu $5 \%$.

Berdasarkan rumus tersebut dapat ditentukan bahwa jumlah sampel 74,79 dibulatkan menjadi 75 , dengan jumlah populasi sebanyak 92 dosen. Cara mendapatkan sampel menggunakan teknik Sampel Acak Berstrata Proporsional. Sampel diambil dengan random/acak dilakukan melalui insidental.

\section{Metode Skala Pengukuran}

Penggunaan skala pengukuran untuk menyusun data dari kuesioner untuk menilai tiap-tiap tanggapan responden diukur dengan mmemakai skala likert. Sugiyono (2016), skala likert dipergunakan menilai perilaku, persepsi dan pendapat seorang dan kelompok orang mengenai permasalahan sosial.

\section{Pengujian Validitas}

Uji validitas ditujukan menghitung yang seharusnya dihitung (Sugiyono, 2016). Instrumen yang lolos punya arti alat ukur yang dipakai dalam memperoleh data (mengukur) valid. Rumus untuk uji validitas ialah Product Moment Pearson,

$$
\mathrm{r}_{\text {hitung }}=\frac{\mathrm{n} \Sigma \mathrm{xy}-\left(\sum \mathrm{x}\right)(\Sigma \mathrm{y})}{\sqrt{\left(\mathrm{n} \sum x^{2}-(\Sigma \mathrm{x})^{2}\right)\left(\mathrm{n} \sum \mathrm{y}^{2}-(\Sigma \mathrm{y})^{2}\right)}}
$$

Keterangan:

$\mathrm{r}_{\text {hitung }}=$ Koefisien korelasi

$\Sigma \mathrm{X}=$ Jumlah skor item

$\mathrm{XY} \quad=$ Jumlah skor total (seluruh item)

$\mathrm{N} \quad=$ Jumlah responden

Instrumen untuk dikatakan lolos jika $r_{\text {hitung }} \geq$ $r_{\text {tabel }}\left(r_{\text {hitung }} \geq 0,361\right)$.

\section{Pengujian Reliabilitas}

Sugiyono Setelah dikatakan valid maka instrumen akan di uji reliabilitasnya. Menurut Sugiyono (2016), alat yang reliabel ialah alat yang jika dipakai berkalii-kali mengukur obyek yang sama, hasilnya akan sama. Uji reliabilitas menngunakan rumus Alpha,

Keterangan:

$$
\mathrm{r}_{11}=\left[\frac{\mathrm{k}}{\mathrm{k}-1}\right]\left[1-\frac{\sum \mathrm{s}_{\mathrm{i}}}{\mathrm{S}_{\mathrm{i}}}\right]
$$

$\mathrm{r}_{11}=$ Nilai reliabilitas

$\sum S_{\mathrm{i}}=$ jumlah varians skor tiap-tiap item

$\mathrm{St}=$ Varians total

$\mathrm{K}=$ jumlah item

Adapun kriteria instrumen untuk dikatakan reliabel adalah jika Cronbach's Alpha $\geq 0,70$.

\section{Pengujian Asumsi Klasik}

Untuk mengetahui analisis data mengecek hipotesis dapat dilanjutkan, perlu dilakukan beberapa cara analisis data dimana diharuskan melakukan uji syarat analisis berupa uji normalitas, linieritas, multikolinieritas dan uji heteroskesdastisitas. Jika regresi linear memenuhi uji asumsi tersebut maka merupakan regresi yang baik.

\section{Metode Analisis}

Mengelompokkan data berdasar faktor serta karakter responden, gambaran data berdasar variabel semua responden, menyediakan tiap faktor yang diobservasi, melaksanakan hitungan dalam merespon rumusan masalah, melaksanakan hitungan mengetes hipotesis yang tunjukkan (Sugiyono, 2016).

1. Analisis Statistik Deskriptif

Penjabaran ini dipakai untuk tahu pada rentang skala mana saja ketetapan bisa diperoleh. Secara matematis, perhitungan rentang skala menggunakan rumus sebagai berikut:

$$
\mathrm{Rs}=\frac{\mathrm{Rt}-\mathrm{Rr}}{\mathrm{M}}
$$

Keterangan :

Rs = Rentang Skala 


$$
\begin{array}{ll}
\mathrm{Rt} & =\text { Rentang Tertinggi } \\
\mathrm{Rr} & =\text { Rentang Terendah } \\
\mathrm{M} & =\text { Jumlah Jawaban }
\end{array}
$$

\section{Analisis Regresi Liniear Berganda}

Model regresi akan menghasilkan penduga yang tidak bias jika memenuhi asumsi klasik, antara lain normalitas data, bebas multikolinieritas, bebas autokorelasi dan bebas heteroskedastisitas.

\section{Koefisien Korelasi (R)}

Analisis korelasi adalah cara supaya tahu/tidak adanya hubungan antar variabel. Dari analisis korelasi, dapat diketahui

Koefisien determinasi pada persamaan struktural menandakan varian variabel laten endogen/dependen yang dapat diuraikan dengan simultan oleh variabel-variabel laten eksogen/independen. Semakin tinggi nilai $\mathrm{R}^{2}$,

\section{HASIL DAN PEMBAHASAN}

Dalam penelitian ini menyebarkan 75 buah kuesioner tenaga akuntan pendidik di Bogor. Kuesioner ini terdiri dari tiga variabel, yaitu mengenai kompetensi akuntan pendidik, etika profesional akuntan pendidik dan akuntabilitas kinerja akuntan pendidik. gambaran mengenai tenaga akuntan pendidik hubungan antar variabel tersebut, yaitu merupakan suatu hubungan kebetulan atau memang hubungan yang sebenarnya (Riduwan, 2013).

\section{Pengujian Hipotesis}

Mengetahui pengaruh simultan digunakan uji $\mathrm{F}$ serta taraf signifikansi $(\alpha)=$ 0,05 yang dapt membuktikan menunjukkan statistik keseluruhan koefisien regresi signifikan dalam pengaruhi faktor dependen. Sementara itu uji $\mathrm{T}$ dengan sinifikansi $(\alpha)=$ 0,05 dipergunakan mengetahui pengaruh secara parsial.

\section{Koefisien Determinasi $\left(\mathrm{R}^{2}\right)$}

maka semakin besar variabel-variabel eksogen/independen tersebut dapat menjelaskan variabel endogen/independen sehingga semakin baik persamaan struktural.

di Bogor yang menjadi responden dalam penelitian, berikut ini akan diuraikan pengelompokkan responden berdasarkan usia, jenis kelamin dan mata kuliah. Adapun data yang penulis peroleh mengenai profil responden adalah sebagai berikut:

Tabel 2. Rekapitulasi Karakteristik Mahasiswa

\begin{tabular}{cccc}
\hline No & Karakteristik & Ciri-ciri Doden & Jumlah Dosen (Orang) \\
\hline 1 & Usia & $20-50$ tahun & $75(100 \%)$ \\
2 & Jenis Kelamin & Perempuan & 43 \\
& & Laki-Laki & 32 \\
3 & Mata Kuliah & & $75(100 \%)$ \\
\hline
\end{tabular}

Sumber: Data diolah (2017)

Bahwa karakteristik responden terbanyak adalah laki-laki sebesar 57\%, ini menggambarkan jika separuh dosen atau tenaga pengajar PTS Bogor didominasi oleh laki-laki. Sebanyak 45\% mayoritas responden berusia 40-49 tahun ini menggambarkan bahwa usia tersebut ialah usia aktif dosean atau tenaga pengajar PTS Bogor dan sebanyak $19 \%$ responden mengajar mata kuliah auditing, ini menggambarkan bahwa responden adalah benar-benar dosen auditing dan sesuai dengan objek pada penelitian.

\section{Uji Validitas}

Uji validitas ditujukan menghitung yang seharusnya dihitung (Sugiyono, 2016). Instrumen untuk dikatakan lolos jika $r_{\text {hitung }} \geq$ $r_{\text {tabel }}$ ( $r_{\text {hitung }} \geq 0,361$ ). Hasil perhitungan menggunakan SPSS 22.0, adalah sebagai berikut.

Tabel 3. Rekapitulasi Instrumen Valid

\begin{tabular}{llc}
\hline \multicolumn{1}{c}{ Variabel } & \multicolumn{1}{c}{ Butir Pertanyaan Valid/Lolos } & Kesimpulan \\
\hline \multirow{2}{*}{ Kompetensi Akuntan Pendidik $\left(\mathrm{X}_{1}\right)$} & $1,2,3,4,5,13,14,15,16,17,18,19$, & \\
& $20,21,22,23,24,25,29,30,31,32,33$ & Valid \\
& dan 34. & \\
Etika Profesional $\left(\mathrm{X}_{2}\right)$ & $1,2,3,4,5,7,8,9,12,13,14,15,16$, & Valid \\
\hline
\end{tabular}


$20,21,22,23,24,25,26,27,28,29,33$, $34,35,36,37,38,39,40,42,43$ dan 44 .

Akuntabilitas Kinerja Akuntan Pendidik $1,2,3,4,5,6,7,8,9,10,11,12,13,14$, (Y) 15 dan 16.

Valid

Sumber: Data Diolah, 2017

\section{Uji Reliabilitas}

Setelah dikatakan valid maka instrumen akan di uji reliabilitasnya. Menurut Sugiyono (2016), alat yang reliabel ialah alat yang jika dipakai berkalii-kali mengukur obyek yang sama, hasilnya akan sama. Adapun kriteria instrumen untuk dikatakan reliabel adalah jika Cronbach's Alpha $\geq 0,70$. Hasil perhitungan kedua uji tersebut sebagai berikut:

Tabel 4. Uji Reliabilitas Instrumen

\begin{tabular}{lcc}
\hline \multicolumn{1}{c}{ Variabel } & Nilai Cronbach's Alpha & Kesimpulan \\
\hline Kompetensi Akuntan Pendidik $\left(\mathrm{X}_{1}\right)$ & 0,906 & Reliabel \\
Etika Profesional $\left(\mathrm{X}_{2}\right)$ & 0,946 & Reliabel \\
Akuntabilitas Kinerja Akuntan Pendidik $(\mathrm{Y})$ & 0,919 & Reliabel \\
\hline
\end{tabular}

Sumber: Data Diolah, 2017

Hasil Analisis Statistik Deskriptif

Adapun analisa dengan statistik deskriptif dilakukan terhadap 293 responden sebagai berikut.

Tabel 5. Statistik Deskriptif

\begin{tabular}{|c|c|c|c|c|}
\hline & & $\mathrm{X}_{1}$ & $\mathrm{X}_{2}$ & $\mathrm{Y}$ \\
\hline \multirow{2}{*}{$N$} & Valid & 75 & 75 & 75 \\
\hline & Missing & 0 & 0 & 0 \\
\hline Mean & & 106,55 & 159,17 & 72,25 \\
\hline Median & & 107,00 & 161,00 & 73,00 \\
\hline Mode & & 107 & 162 & 73 \\
\hline Std. Deviation & & 6,101 & 9,249 & 4,214 \\
\hline Variance & & 37,224 & 85,551 & 17,759 \\
\hline Range & & 38 & 50 & 21 \\
\hline Minimum & & 81 & 130 & 59 \\
\hline Maximum & & 119 & 180 & 80 \\
\hline Sum & & 7991 & 11938 & 5419 \\
\hline
\end{tabular}

Sumber: Data Diolah, (2017)

Berdasarkan tabel menunjukkan bahwa :

a. Berdasarkan data penelitian yang dihimpun lapangan terhadap variabel kompetensi akuntan pendidik dengan 24 butir pertanyaan valid, diperoleh nilai rata-rata 106,55 nilai tengah 107,00 , nilai yang paling sering muncul adalah 107, simpangan baku 6,101, keragaman data kompetensi akuntan pendidik menunjukkan nilai sebesar 37,224, mutu rendah sebanyak 81 juga mutu tinggi sebanyak 119.

b. Berdasarkan data penelitian yang dihimpun lapangan terhadap faktor lingkungan kerja dengan 36 butir pertanyaan valid, diperoleh nilai rata-rata 159,17 , nilai tengah 161,00 , nilai yang paling sering muncul adalah 162 , simpangan baku 9,249, keragaman data etika profesional menunjukkan nilai sebesar 85,551, mutu rendah sebanyak 130 dan mutu tinggi sebanyak 180 . c. Berdasarkan data penelitian yang dihimpun lapangan terhadap variabel Akuntabilitas Kinerja Akuntan Pendidik dengan 16 butir pertanyaan valid, diperoleh nilai rata-rata 72,25 , nilai tengah 73 , nilai yang paling sering muncul adalah 73 , simpangan baku 4,214 , keragaman data akuntabilitas kinerja akuntan pendidik menunjukkan nilai sebesar 17,759, mutu rendah sebanyak 59 dan mutu tinggi sebanyak 80 .

\section{Pengujian Asumsi Klasik}

Untuk tahu analisis data untuk pengujian hipotesis dapat dilanjutkan, perlu dilakukan beberapa cara olah data dimana diharuskan melakukan uji syarat analisis berupa uji normalitas, linieritas, multikolinieritas dan uji heteroskesdastisitas.

1. Uji Normalitas

Uji normalitas data dilakukan memakai SPSS 20.0 dengan metode One Sample 
Kolmogorov Smirnov (KS). Kriteria uji dari metode $K S$ adalah skor variabel dinilai terdistribusi normal jika derajat signifikansi variabel $>0,05$. Hasil tes derajat signifikan sebesar 0,051 atau >0,05, dengan demikian skor variabel kompetensi akuntan pendidik dapat disimpulkan penyebaran data normal. Hasil tes derajat signifikan sebesar 0,145 atau $>0,05$, dengan demikian skor variabel etika profesional dapat disimpulkan penyebaran data normal. Hasil tes derajat signifikan sebesar 0,160 atau > 0,05 , dengan demikian skor variabel akuntabilitas kinerja akuntan pendidik dapat disimpulkan penyebaran data normal.

2. Uji Linieritas

Uji linearitas dilakukan supaya tahu distribusi skor dependen variabel dengan independen variabel berpola linear atau tidak. Hasil uji linearitas sebesar 0,000 atau $<0,05$, dengan demikian bisa dirangkum jika variabel kompetensi akuntan pendidik dengan akuntabilitas kinerja akuntan pendidik berpola linear. Hasil uji linearitas sebesar 0,000 atau $<0,05$, dengan demikian bisa dirangkum jika variabel etika profesional dengan akuntabilitas kinerja akuntan pendidik berpola linear.

3. Uji Multikolonieritas

Uji multikolinearitas dipakai supaya tahu ada atau tidaknya perubahan asumsi klasik multikolinearitas, yakni ada keterkaitan linear variabel independen dalam model regresi. diketahui nilai VIF (Variance Inflation Factor) kedua variabel kompetensi akuntan pendidik $=1,950$; etika profesional $=1.950$, masing-masing variabel independen memiliki VIF (Variance Inflation Factor) tidak lebih dari 10 dan nilai tolerance tidak kurang dari 0,1. jadi bisa dikatakan model regresi linier berganda bebas dari asumsi klasik statistik dan dapat digunakan dalam penelitian.

4. Uji Heterokedastisitas

Uji heteroskedastisitas bermaksud menegtes apa dalam model regresi terjadi ketidaksamaan variance dari residual satu pengamatan ke pengamatan lainnya. Diketahui bahwa grafik scatterplot pada uji ini tidak ada pola yang jelas serta titik tersebar diatas dan dibawah angka 0 (nol) pada sumbu Y, maka tidak terjadi heteroskedastisitas.

\section{Hasil Uji Regresi Linier Berganda}

Bentuk persamaan dinilai memakai regresi linear berganda. Adapun persamaan tersebut menunjukkan dampak etika profesional, kompetensi akuntan pendidik atas akuntabilitas kinerja akuntan pendidik, dari hasil penelitian, maka diperoleh suatu persamaan regresi dengan model taksiran seperti berikut ini :

$$
Y=18.858+0,410 X_{1}+0.061 X_{2}
$$

Berdasarkan persamaan tersebut maka diketahui

a. Nilai 0,410 merupakan koefisien regresi faktor $X_{1}$ untuk nilai $b_{1}$ dalam persamaan regresi linear berganda $Y=a+b_{1} X_{1}+b_{2} X_{2}$ jadi $b_{1}=0,410$ artinya setiap peningkatan 1 point dari kompetensi akuntan pendidik maka akan mempengaruhi akuntabilitas kinerja akuntan pendidik sebesar 0,410 poin dan variabel bebas lainya konstan.

b. Nilai 0,061 merupakan nilai koefisien untuk variable $X_{2}$ untuk nilai $b_{2}$ dalam persamaan regresi linear berganda $Y=a+b_{1} X_{1}+b_{2} X_{2}$ jadi $b_{2}=0,061$ artinya setiap peningkatan 1 point dari etika profesional maka akan mempengaruhi akuntabilitas kinerja akuntan pendidik sebesar 0,061 poin dan variabel bebas lainnya konstan. Sedangkan nilai 18,858 merupakan konstanta untuk nilai a yang berarti nilai $Y$ apabila $X=0$. Tanda + (positif) pada variabel etika profesional, kompetensi akuntan pendidik artinya apabila kompetensi akuntan pendidik serta etika profesional ditingkatkan maka akuntabilitas kinerja akuntan pendidik akan meningkat.

\section{Pengujian Koefisien Korelasi $\left(\mathbf{R}^{2}\right)$}

Keterkaitan kompetensi akuntan pendidik, etika profesional dengan akuntabilitas kinerja akuntan pendidik pada PTS Bogor memakai teknik korelasi product moment didapatkan koefisien korelasi $\mathrm{r}_{\mathrm{y} \cdot 12}=$ 0,694. Keterkaitan dua-duanya signifikan, bermakna keterkaitan positif dengan mutu hubungan kuat kompetensi akuntan pendidik dengan etika profesional atas akuntabilitas kinerja akuntan pendidik.

\section{Pengujian Koefisien Determinasi}

Analisis koefisien determinasi memperlihatkan seberapa besar sumbangan 
persentase dampak kompetensi akuntan pendidik, etika profesional akuntan pendidik pada akuntabilitas kinerja akuntan pendidik. Diperloleh nilai koefisien determinasi $R$ Square sebesar 0,467 atau $46,7 \%$. Hal tersebut memperlihatkan persentase sumbangan dampak variabel kompetensi akuntan pendidik, etika profesional akuntan pendidik pada akuntabilitas kinerja akuntan pendidik sebesar 46,7\%. Sedangkan, sisanya 53,3\% dipengaruhi variabel diluar penelitian yang tidak dimasukan dalam model penelitian ini.

\section{Uji Hipotesis Simultan}

Membuktikan bersama-sama variabel kompetensi akuntan pendidik serta etika profesional atas akuntabilitas kinerja akuntan pendidik mempergunakan statistik uji-F. Dan hasil perhitungan diperoleh bahwa nilai $F_{\text {hitung }}$ sebesar 33,421 dan $F_{\text {tabeluntuk }} \alpha=0,05$, dengan df $1=2$ dan df $2=71$ sebesar 3,124 yang dimana bisa dilihat bahwa $\mathrm{F}_{\text {hitung }}$ lebih besar dari $F_{\text {tabel }}(33,421>3,124)$ bisa disimpulkan $\mathrm{H}_{0}$ ditolak dan $\mathrm{H}_{\mathrm{a}}$ diterima artinya dengan ringkat kepercayaan 95\% variabel independen kompetensi akuntan pendidik $\left(\mathrm{X}_{1}\right)$, etika profesional $\left(\mathrm{X}_{2}\right)$, mempengaruhi positif simultan atas akuntabilitas kinerja akuntan pendidik (Y). Hal tersebut seperti yang dilaksanakan Utami (2010), menunjukkan bahwa komitmen organisasional dan komitmen profesional terbukti mempengaruhi positif atas motivasi dosen akuntansi.

\section{Uji Hipotesis Parsial}

1. Pengaruh Kompetensi Akuntan Pendidik $\left(\mathrm{X}_{1}\right)$ Terhadap Akuntabilitas Kinerja Akuntan Pendidik (Y). Hasil perhitungan pada tabel diperoleh $t_{\text {hitung }}$ pada kompetensi akuntan pendidik $\left(\mathrm{X}_{1}\right)$ sebesar 5,014 dan nilai $t_{\text {tabel }}$ untuk $\alpha=0,05$ dengan derajat kebebasan $75-2-1=72$ sebesar 1,993 berarti $t_{\text {hitung }}>t_{\text {tabel }}(5,014>1,993)$. Maka $\mathrm{H}_{\mathrm{a}}$ diterima dan $\mathrm{H}_{0}$ ditolak, artinya kompetensi akuntan pendidik $\left(\mathrm{X}_{1}\right)$ mempengaruhi positif atas akuntabilitas kinerja akuntan pendidik (Y). Didukung penelitian sudah dilaksanakan Nongkeng (2011), menunjukkan bahwa kinerja berpengaruh langsung serta signifikan atas kepuasan kerja akuntan pendidik.

2. Pengaruh Etika Profesional $\left(\mathrm{X}_{2}\right)$ Terhadap Akuntabilitas Kinerja Akuntan Pendidik (Y)
Hasil perhitungan pada tabel diperoleh $t_{\text {hitung }}$ pada variabel etika profesional $\left(\mathrm{X}_{2}\right)$ sebesar 1,124 dan nilai t tabel untuk $\alpha=0,05$ dengan derajat kebebasan 75-2-1 $=72$ sebesar 1,993 berarti $t_{\text {hitung }}>t_{\text {tabel }}(1,124>$ 1,993). Dari itu $\mathrm{H}_{a}$ ditolak dan $\mathrm{H}_{0}$ diterima, artinya etika profesional $\left(\mathrm{X}_{2}\right)$ tidak mempengaruhi positif atas akuntabilitas kinerja akuntan pendidik (Y). Penelitian sama dilakukan Guspika (2009), menunjukkan bahwa di dalam dharma penelitian dan dharma pengabdian kepada masyarakat, masih banyak dosen PNS Indonesia merasa sulit dan belum konsisten atau jarang menerapkan prinsip etika profesi.

\section{KESIMPULAN}

Hasil penelitian disimpulkan bahwa:

1. Hasil Uji $F$ bahwa etika profesional, kompetensi akuntan pendidik bersamasama mempengaruhi secara signifikan atas akuntabilitas kinerja akuntan pendidik.

2. Hasil Uji t bahwa kompetensi akuntan pendidik mempengaruhi signifikan atas akuntabilitas kinerja akuntan pendidik, sedangkan etika profesional tidak mempengaruhi signifikan atas akuntabilitas kinerja akuntan pendidik.

Berdasarkan hasil penelitian, antara lain :

a. Bagi akuntan pendidik PTS diharapkan lebih bisa memacu/meningkatkan kompetensi akuntan pendidik dengan sikap positif terhadap tugas yang diemban dengan menjalankan fungsi dan kedudukannya melalui metode praktik kompetensi profesional, kompetensi kepribadian, kompetensi pendagogik, dan kompetensi sosial.

b. Bagi PTS harus meningkatkan etika profesional dosen dan memotivasi dosen melalaui perhatian kepentingan publik, integritas, objektivitas dan independen, serta due care, agar etika profesional akan meningkat.

c. Bagi peneliti selanjutnya. Metode peneliti gunakan memiliki keterbatasan untuk mengontrol keakuratan jawaban responden. maka dari itu penelitian lanjutan perlu mempertimbangkan suatu metode lebih tepat supaya sampel diperoleh representatif supaya hasil riset dilakukan bisa di generalisasi. 


\section{DAFTAR PUSTAKA}

Bertens, K, 2013. Prespektif Etika Baru, 55 Esai Tentang Masalah Aktual, PT. Kanisius, Yogyakarta. , 2013. Etika, Edisi Revisi, PT. Kanisius, Yogyakarta.

Johnson, Charles E. et all., 1980. Psychology and Teaching: Bombay, D.B. Taraporevala Sons \& Co. Private Limited.

Poerwadarminta, W. J. S, 2005. Kamus Umum Bahasa Indonesia, PN. Balai Pustaka, Jakarta.

Rachmawati, Tutik dan Daryanto, 2013. Penilaian Kinerja Profesi Guru dan Angka Kreditnya, Gava Media, Yogyakarta.

Reski, 2013. Perbandingan Persepsi Akuntan dan Mahasiswa Akuntansi Terhadap Etika Penyusunan Laporan Keuangan, Skripsi, Makasar, Universitas Hasanuddin.

Riduwan, 2013. Belajar Mudah Penelitian Untuk Guru, Karyawan dan Peneliti Pemula, Alfabeta, Bandung.

Spencer, M. Lyle and Spencer, M. Signe, 1993, Competence At Work, Model For Superior.
Sugiyono, 2013. Metode Penelitian Kuantitatif, Kualitatif danR\&D, CV. Alfabaeta, Bandung.

2014. Metode Penelitian Kuantitatif, Kualitatif danR\&D, CV. Alfabaeta, Bandung.

2016. Metode Penelitian Kuantitatif, Kualitatif danR\&D, CV. Alfabaeta, Bandung.

Suyanto dan Jihad, A, 2013. Menjadi Guru Profesional Strategi Meningkatkan Kulaifikasi dan Kualitas Guru di Era Global, Esensi Erlangga Group, Jakarta.

Wibowo, 2012. ManajemenKinerja (Edisi 3), Rajawali pers, Jakarta.

Yuthadiana, Vina R, 2015. Analisis Kebutuhan Program Pelatihan dan Pengembangan Berdasarkan Kompetensi pada Talents Bank BJB Cabang Hasyim Ashari, Tesis di Universitas Widyatama, Bandung.

http://marketeers.com/hadapi-mea-akuntanindonesia-perlu-berbenah/Diakses pada tanggal 25 Februari 2017 Pukul 20:17 WIB.

http://forlap.dikti.go.id/prodi Diakses pada tanggal 02 Mei 2017 Pukul 15.37 WIB.

http://id.m.wikipedia.org Diakses pada tanggal 10 Juli 2017 Pukul 20.05 WIB. 